\title{
IS MTHFR POLYMORPHISM A RISK FACTOR FOR ALZHEIMER'S DISEASE LIKE APOE?
}

\author{
Liana Lisboa Fernandez', Rosane Machado Scheibe ${ }^{2}$
}

\begin{abstract}
Background: The role of methylenetetrahydrofolate reductase (MTHFR) gene polymorphisms as risk factors for the occurence of Alzheimer's disease $(A D)$ is still controversial: Objective: To verify the association between MTHFR and apolipoprotein E (APOE) polymorphisms and Alzheimer's disease. Method: This work was conducted as a case-control study. Cases included thirty patients with probable AD. Controls were constituted by 29 individuals without dementia according to neuropsychological tests paired to age, sex, race and educational level. DNA was isolated from peripheral leukocytes of anticoagulated venous blood. Genotyping of APOE and MTHFR were performed by DNA amplification and digestion. The frequences of APOE and MTHFR genotypes were submitted by chi-square test corrected by Fisher test; the APOE genotypes, to chi-square linear tendency test and the frequences of MTHFR mutant and AD, by stratificated anlysis adjust by Mantel-Haenszel method. Results: There was significant difference about APOE4 and APOE2 in the groups. $(p=0.002)$ The odds ratio increased exponentially with the increased number of E4 allele $\left(\chi^{2}\right.$ linear tendency test). No significant difference was detected on MTHFR genotypes in both case and control groups. Conclusion: The APOE4 is a risk factor and demonstrated a dose-depenent effect while APOE2 allele conferred a protection to AD. The MTHFR mutation had no correlation with AD.
\end{abstract}

KEY WORDS: Alzheimer's disease, apolipoprotein E, methylenetetrahydrofolate reductase, PCR-RFLP, risk factors.

\begin{abstract}
Polimorfismo da MTHFR é um fator de risco para demência de Alzheimer como APOE?
RESUMO - Introdução: O papel do polimorfismo do gene da metilenotetrahidrofolato redutase (MTHFR) como um fator de risco para demência de Alzheimer (DA) é controverso ainda. Objetivo: Verificar a associação entre os polimorfismos da MTHFR e apolipoproteína E (APOE) e DA. Método: O trabalho foi conduzido como um estudo caso-controle. Trinta pacientes com DA provável foram incluídos no grupo caso. Vinte e nove indivíduos sem demência comprovadas por testes neuropsicológicos, emparelhados pela idade, sexo, cor e nível educacional constituíram o grupo controle. DNA foi isolado de leucócitos periféricos extraídos de sangue venoso anticoagulado. Genótipos de APOE e MTHFR foram realizados por amplificação de DNA e digestão. As freqüências dos genótipos da APOE e MTHFR foram submetidas ao teste do chi-quadrado corrigido pelo teste de Fisher; os genótipos da $A P O E$, ao teste do chi-quadrado com tendência linear e as freqüências da MTHFR mutante e DA à análise estratificada corrigida pelo método de Mantel-Haenszel. Resultados: Houve diferença significativa entre APOE4 e APOE2 nos grupos $(p=0,002)$. O odds ratio aumentou exponencialmente com o aumento do número de alelo E4 (teste $\chi^{2}$ com tendência linear). Nenhuma diferença significativa foi detectada nos genótipos da MTHFR em ambos grupos caso e controle. Conclusão: O alelo APOE4 é um fator de risco e demonstrou efeito dose-dependente enquanto o alelo E2 conferiu proteção para DA. A mutação da MTHFR não teve correlação dom DA.
\end{abstract}

PALAVRAS-CHAVE: doença de Alzheimer, apolipoproteína E, metilenotetrahidrofolato redutase, fatores de risco.

The number of elder people has raised with the increase of life expectancy and as consequence, the prevalence of age-related disease. Alzheimer's disease (AD) is the leading cause of dementia in the elderly. It is a multifactorial pathology resulting of the interaction of both genetics and environmental factors. $A D$ is an illness resulting from selective damage of specific neuronal circuits in the neocortex, hippocampus, and basal forebrain cholinergic system. Affected regions show senile plaques, comprised of neurites displayed around extracellular deposits of $\beta$-amyloid peptides; and many neurons develop neurofibrillary tangles, which reflect the local accumulation of abnormal intracytoplas-

Biomedical Geronthology Institute, PUCRS, Porto Alegre RS, Brazil: ${ }^{1}$ Professor, MSc, Neurologist, ${ }^{2}$ Professor, PhD, Pharmachologist. CAPES Support.

Received 23 April 2004, received in final form 22 July 2004. Accepted 21 September 2004.

Dra. Liana Lisboa Fernandez - Rua Coronel Bordini 675/204 - 90440-001 Porto Alegre RS - Brasil. 
mic filaments, composed of hyperphosphorylated isoforms of the tau protein'. Over one hundred rare, highly penetrant mutations have been described in three genes (APP, PSEN1, PSEN2) for early-onset familial $A D^{2-4}$. In the more common late-onset form, a polymorphism in the apolipoprotein $E$ (APOE) gene has been associated with increased susceptibility 5 .

APOE is a plasma protein involved in cholesterol transport. It is produced and secreted in the central nervous system (CNS) by astrocytes. APOE synthesis is increased following injury and is implicated in the growth and repair of nervous system during development or after injury. APOE is bound to extracellular senile plaques, to intracellular neurofibrillary tangles, and at sites of cerebral vessel congophilic angiopathy ${ }^{6}$. The APOE gene has three alleles: E2, E3 and E4. The variant APOE4 is a major risk factor for the development of $A D^{7-13}$ However, APOE4 is neither necessary nor sufficient to cause $A D$. So it is clear that other yet unknown genes, and environmental factors must be involved in its etiology ${ }^{14}$.

Low blood levels of folate and vitamin B12, and elevated homocysteine levels were associated with poor cognitive performace in elderly people ${ }^{15-19}$. Possible biochemical interpretation of the putative effects of this low vitamin status and elevated homocysteine levels on cognitive decline can be made on basis of the pathway of one-carbon metabolism $^{15}$. In this pathway, the methylenetetrahydrofo- late reductase (MTHFR) is a central enzyme forming the substrate needed for the transferring reaction. Dysfunctional one-carbon metabolism gives rise to various pathogenetic mechanisms: insufficient DNA synthesis, transmethylation insufficiency and toxicity of homocysteine and related compounds?. Furthermore, insufficient one-carbon metabolism has been suggested to have a contributory role in the development of dementia and has found to be significant in $A D$ patient ${ }^{9}$. It has been recently reported a C677T mutation on the MTHFR gene which produces a thermolabile variant. In its homozygous form, this variant possesses a reduced overall enzyme activity to less than $30 \%$ of normal, resulting on increased serum homocysteine levels $s^{9,20}$.

We examined both the APOE polymorphism and MTHFR mutation in a group of $A D$ individuals and in controls, to assess whether these genetic factors increase the risk for this illness.

\section{METHOD}

Patients - We investigated 29 Caucasian patients (24 women and 5 men) and 1 Afro-Brazilian patient (1 man) all over 55 years old (mean $73.5 \pm 18.5$ ) with the diagnosis of Probable AD according to NINCDS-ADRDA criteria and an Inventory of Diagnostic Clinic Features of Disease of Alzheimer Type 21,22. All cases were sporadic, unrelated and were recruited at an outpatient clinic (Clínica médica Salvador Dali and Serviço de Geriatria Hospital São Lucas da PUCRS) in Porto Alegre city.

Table 1. Sample outline studied.

\begin{tabular}{llll}
\hline & $\begin{array}{l}\text { Case } \\
\mathrm{n}=30\end{array}$ & $\begin{array}{l}\text { Controls } \\
\mathrm{n}=29\end{array}$ & $\mathrm{p}$ \\
\hline Sex, No (\%) F & $24(80)$ & $24(82.7)$ & \\
Race, No (\%) white & $29(96.9)$ & $29(100)$ & \\
Age, years & $73,5 \pm 18.5$ & $76 \pm 17$ & \\
Educational level, <8 years & $70 \%$ & $72.4 \%$ & \\
Discrete periventricular white & & & \\
matter lucencies in neuroimaging & & & \\
(CT or MRI) with encephalic atrophy & $70 \%$ & & \\
Smoking use, yes & $15(50)$ & $10(34,5)$ & 0.346 \\
Antinflamatory drugs, yes & $17(56.6)$ & $15(51.7)$ & 0.905 \\
Familial history, yes & $8(26.7)$ & $5(17.2)$ & 0.576 \\
Hormonal replacement, yes & $9(12.5)$ & $6(4.2)$ & $0.304^{*}$ \\
Diabetes mellitus, yes & $8(26.7)$ & $2(6.9)$ & $0.044^{*}$ \\
Hypercholesterolemy, yes & $18(60)$ & $14(48.3)$ & 0.520 \\
Atherosclerosis, yes & $12(40)$ & $15(55.2)$ & 0.364 \\
Atrial fibrilation, yes & $2(6.7)$ & $6(20.7)$ & $0.116^{*}$ \\
Arterial hypertention, yes & $15(50)$ & $13(44.8)$ & 0.891 \\
\hline
\end{tabular}

The data were presented in numbers (percentage) and $p$ calculated by $\chi^{2}$ corrected by Yates test; ${ }^{*}$ ) corrected by Fisher test. 
We evaluated 29 Caucasian control individuals (24 women and 5 men), without dementia according to neurophychological tests matched for age, sex and educational level with case group.

The sample outline was demonstrated on Table 1.

Consent for participation in the study was provided by the subjects themselves or their legal guardians.

Ethics - The research protocol was approved by Scientific and Ethics Committes of the University.

Laboratory methods - DNA from each patient was isolated from peripheral leukocytes of $1 \mathrm{~mL}$ venous blood, anticoagulated with ethylenediaminetetraacetic acid (EDTA) by kit GFX Genomic Blood DNA Purification (Amersham Biosciences, USA). Blood samples were stored at $20^{\circ} \mathrm{C}$ for analysis.

APOE genotyping was performed by amplification of the third exon of the APOE gene by polymerase chain reaction (PCR) with primers described by Wenham et al. ${ }^{23}$, followed by an enzymatic clivage with the restriction enzyme Hhal (RFLP) ${ }^{20}$. Fragments of $72 \mathrm{bp}$ and $48 \mathrm{bp}$ are produced in APOE4, fragments of $91 \mathrm{bp}$ and $83 \mathrm{bp}$ are produced in APOE2 an $91 \mathrm{bp}$ and 48bp are generated in APOE3. (Fig 1).
To detect the mutant allele of MTHFR, the same leukocytes DNA samples were examined. The PCR was performed with the primers described by Nishiyama et al. using Hinfl restriction enzyme to identify the muta$\operatorname{tion}^{20}$. The mutant allele generated two fragments: $175 \mathrm{bp}$ and 23bp, while the wild-type is not clived and is identified by a 198bp fragment (Fig. 2).

Data analysis - Allele frequences for patients with $A D$ and control subjects were estimated by counting alleles and calculating sample proportions.

Frequences of APOE and MTHFR genotypes in cases and controls were compared using the chi-square test corrected by Fisher test (Stat calc/Epi Info 6).

The APOE genotypes were submitted to chi-square linear tendency test.

The frequences of MTHFR mutant and AD were evaluated after stratificated analysis adjust by Mantel-Haenszel method.

\section{RESULTS}

The APOE alleles frequencies in our control sample were $83 \% \mathrm{E3}, 10 \% \mathrm{E} 4$ and $7 \% \mathrm{E2}$ and in case sample, $63 \% \mathrm{E} 3,35 \% \mathrm{E} 4$ and $2 \% \mathrm{E} 2$. This diference

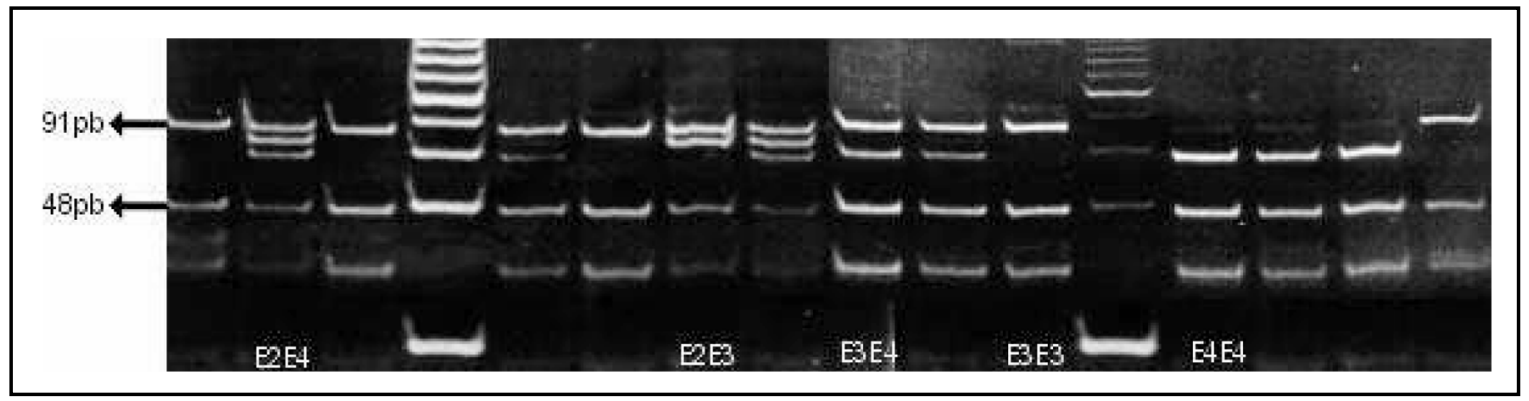

Fig 1. APOE genotypes: polyacrilamide (15\%) gel electrophoresis stained with ethidium bromide. Some representative genotypes and relevant molecular sizes are indicated.

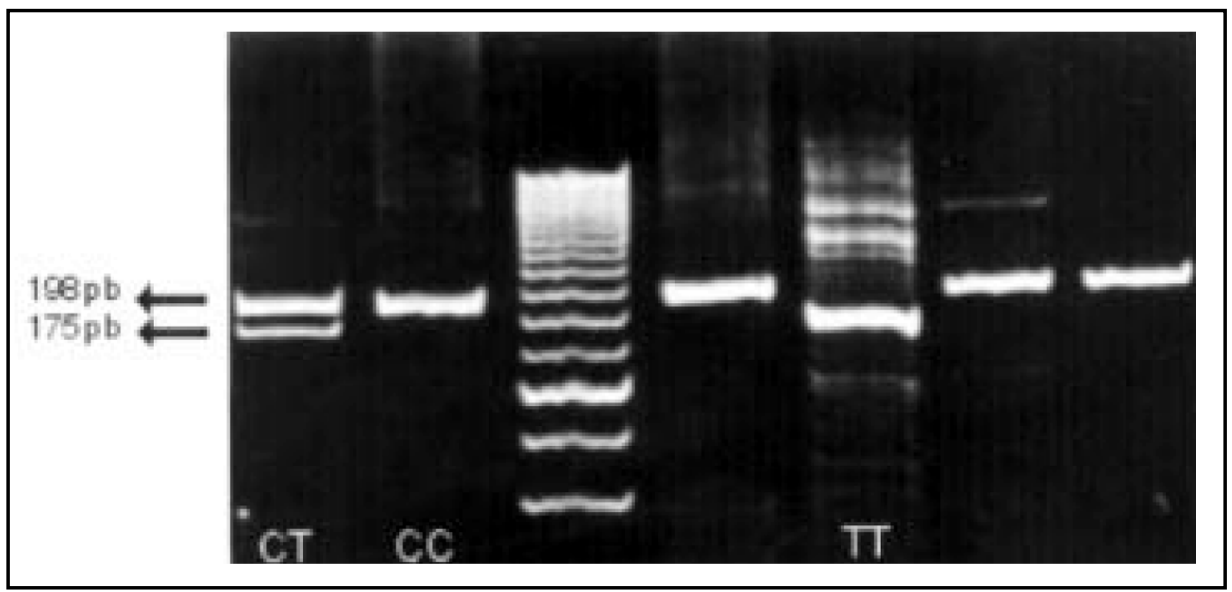

Fig 2. MTHFR genotypes: polyacrilamide (15\%) gel eletrophoresis stained with ethidium bromide. Some representative genotypes and relevant molecular sizes are indicated. 
was significant $(p=0.002)$ calculated by Exact Fisher test.

The genotyping distribution and its impact/significance were analised using the chi-square linear tendency test (Table 2).

The MTHFR alleles frequencies were $65 \%$ allele C, $35 \%$ allele $\mathrm{T}$ in case group while in controls were $71 \%$ and $29 \%$ respectively. This diference was not significant $\left(p=0.508 \chi^{2}\right.$ test)

The interaction of APOE4 allele and MTHFR T (mutation) was demonstrated in Table 3. The genotypes distribution in cases was 35\% CC (wild gene homozigose), 57\% CT and 6\% TT (mutation gene homozigose) while controls it was $52 \%$ CC, $38 \%$ $\mathrm{CT}$ and $10 \% \pi$. This diference was not statistical significant ( $p=0.401$ Exact Fisher test).

\section{DISCUSSION}

The control allele frequencies in our sample were $83 \%$ E3, 10\% E4 and 7\% E2. All controls were Caucasians. In Caucasian populations the E3 allele is the most commonly ocurring: it occurs about $77 \%$. The average frequencies of E4 and E2 are 15\% and $8 \%$ respectively. The $\mathrm{E} 4$ allele frequence varies according to the race. It reaches up to $30-35 \%$ in African and Asian populations. The north European population presents larger frequencies (Finland 22.7\%, Sweden $20.3 \%$ ) than southern countries (Italy $9.4 \%)^{24}$. Andrade et al. found in a populational study in south Brazilian region $81 \% \mathrm{E} 3,11.5 \% \mathrm{E} 4$ and $7.5 \%$ E2 allele frequencies in caucasians while for Afrobrazilians they found $70 \% \mathrm{E} 3,22.5 \% \mathrm{E} 4$ and $7.5 \%$ E2 allele frequencies ${ }^{25}$. Schwanke et al. found in an elderly population in Veranópolis (south Brazilian region) $84 \%$ E3, $11 \%$ E4 and 5\% E2 allele frequencies ${ }^{26}$. The control allele frequencies in our sample were similar to others Caucasian population described in literature.

The E4 allele frequencies were significantly higher in case group than control.The E4 allele frequence was $10 \%$ in control group against $35 \%$ in cases and similar to values reported by Andrade et al $(11.5 \% \text { in controls and } 39 \% \text { in cases })^{25}$. Almeida in São Paulo population find $22.1 \%$ E4 in cases and $8.9 \%$ in controls ${ }^{27}$.

Our study confirms the E4 allele presence as an $A D$ risk factor for this Caucasians sample according to literature data ${ }^{7,8,10,12,13,20,28-30}$. Based on these, it is obvious that APOE4 has a massive impact on the development of $A D$.
The E2 allele presence was significantly different in both groups ( $p=0.002$ Exact Fisher Test). Only $2 \%$ of the demented presented E2 alleles whereas $7 \%$ of normal individuals presented it.

It was demonstrated that AD patients with E2E3 genotype compared with E3E3 presented less $\beta$-amiloid densities in brain cortex moreover reduced amiloid angiopathy ${ }^{31}$. Review articles have suggested a protective effect of E2 allele in AD patients ${ }^{10,12}$. Nevertheless, Molero in an aging study performed in Maracaibo (Venezuela), Almeida in São Paulo (Brazil) and Andrade in Porto Alegre (Brazil) did not find significant association between E2 allele in cases and controls ${ }^{25,27,28}$. In our sample the E2 allele presence suggested a protective effect for $A D$.

Our genotipic distribution showed a strong tendency to increase the risk (OR) to develop $A D$ dependent on genotype. The E2E3 genotype presented like the most protective genotype for $A D(O R=1)$ The genotypes that brings near the $\mathrm{E} 4$ homozigose determined an exponential increase in odds ratio (E3E3 OR=4 ${ }^{1}$ E3E4 OR=4² ; E4E4 OR=4³) (Table 2).

Austin Bradford-Hill describes 8 elements that make evident an effect-cause association. Among

Table 2. APOE genotype distribuition.

\begin{tabular}{llllll}
\hline & & $\begin{array}{l}\text { Cases } \\
\mathrm{n}=30\end{array}$ & $\begin{array}{l}\text { Controls } \\
\mathrm{n}=29\end{array}$ & $\mathrm{OR}^{*}$ & $p$ Fisher \\
\hline E4E4 & 4 & $4(13.3)$ & $0(0.0)$ & 63.0 & 0.029 \\
E4E3 & 17 & $12(40.0)$ & $5(17.2)$ & 15.9 & 0.049 \\
E4E2 e E3E3 & 35 & $14(46.6)$ & $21(72.4)$ & 4.7 & 0.283 \\
E3E2 & 3 & $0(0.0)$ & $3(10.3)$ & 1.0 & \\
\hline
\end{tabular}

$\chi^{2}$ linear tendence test, $p<0.001 ;{ }^{*}$ Agresti ajusted.

Table 3. Association between MTHFR allele $T$ and $A D$ after adjust to stratifed analysis to allele E4 effect.

\begin{tabular}{llll}
\hline Allele status & Cases & Controls & OR (IC95\%) \\
\hline E4 Allele (+) & & & \\
$\begin{array}{l}\text { T Allele (MTHFR) } \\
\text { Positive }\end{array}$ & $\mathrm{n}=17$ & $\mathrm{n}=6$ & \\
$\quad 10(58.8)$ & $4(66.7)$ & $0.71(0.07$ a 6.95$)$ \\
Negative & $7(41.2)$ & $2(33.3)$ & $\mathrm{p}=0.999$ \\
E4 Allele (-) & & & \\
T Allele (MTHFR) & $\mathrm{n}=13$ & $\mathrm{n}=23$ & \\
$\quad \begin{array}{l}\text { Positive } \\
\text { Negative }\end{array}$ & $9(69.2)$ & $10(43.3)$ & $2.92(0.57$ a 15.94) \\
Total & $4(30.8)$ & $13(56.6)$ & $\mathrm{p}=0.254$ \\
& & & $1.80 *(0.51$ a 6.30) \\
\hline
\end{tabular}

Data are presented as number (percentage). *Odds ratio adjusted by Mantel-Haenszel method. 
them, temporality (causes precede the effects), association force (a high related or absolute risk), a dose-effect relation (high doses are related with effect variations) and consistence (other studies, in different times, in different places, with different patients come to the same evidence). The E4 allele presence precedes $A D$ manifestation, the 63 odds ratio of E4E4 genotype was remarkable absolute risk, the E4 allele quantity increases exponentially the $A D$ risk and a lot of studies in different parts of the world comes to the same evidence. So our data confirm a predisposition to develop AD in individuals that present $\mathrm{E} 4$ allele and make clear several Bradford-Hill elements ${ }^{32}$. Sixty-five percent of $A D$ individuals did not present APOE4 allele in our sample. In this cases other risk factors (genetics or environmental) would be acting in the $A D$ development.

Regland et al. related $40 \%$ of heterozigose prevalence in general population (CT), $11 \%$ of polymorphism homozigose (TT) and $49 \%$ wild gene homozigoses (CC) ${ }^{9}$. Nishiyama et al. describe $39 \%$ CC, $45 \%$ CT and $15 \%$ TT similar to Japanese and Canadian population data ${ }^{20}$. Our results (38\% CT, 10\% TT and $52 \% \mathrm{CC}$ ) resemble genotypic distribution related by Regland ${ }^{9}$.

The MTHFR allele frequence did not show significant difference in control and case groups. Nishiyama et al found an increased proportion of senile demented individuals in the MTHFR mutation group, particularly in men. This mutation was more associated with $A D$ than with vascular dementia ${ }^{20}$ In our work no association with MTHFR mutation and $A D$ was found. It could be probably because of the high polymorphism prevalence in general population associated to a limited group sample ( 30 cases and 29 controls). It would be need 60 cases and 120 controls to express really diferences.

Regland et al. found an inverse correlation between MTHFR mutation and APOE4, suggesting that MTHFR mutation is 1.8 times more frequent in the absence of APOE4 ${ }^{9}$. The association rate of MTHFR T allele and AD cases after adjusted for allele E4 effect was not significant, despite it suggested a small tendency of allele $T$ individuals to develop AD (OR=1.80) (Table 3).

Clark et al. Postiglione et al. Brunelli et al. and Prince et al. did not find a significant relation between MTHFR mutation and AD either ${ }^{19,33-35}$. Seripa et al found no difference in MTHFR polymorphism distribuition between AD cases and elderly controls in both American cohort and Italian cohort ${ }^{36}$. Religa et al. found that plasma total homocysteine is increased in AD patients and depended on the MTHFR T/T genotype (mutation homozigoze) in the presence of low folate levels, however the distribuition of MTHFR C677T polymorphism in the Polish population does not differ in AD and controls ${ }^{37}$. Our negative results, in individuals with Probable $A D$, confirmed the lack of association between $A D$ and $\mathrm{C} / \mathrm{T}$ polymorphism in the MTHFR gene.

The main conclusions of this study were: APOE4 allele was a risk factor for AD; APOE2 allele was a protective factor for $A D$; the presence of allele $E 4$ demonstrated a dose-dependent effect, increasing exponentially compared with genotype E2E3; there was a discreet tendency of MTHFR allele T presence in $A D$ patients adjusted to allele E4 efect, but it was not significant; the MTHFR mutation did not demonstrate significant difference in cases and controls.

\section{REFERENCES}

1. Prince DL, Sisodia SS, Borchett DR. Alzheimer disease:when or why? Nature Genetics 1998;19:314-316.

2. Goate A, Chartier-Harlin MC, Mullan M, et al. Segregation of a missense mutation in the amyloid precursor protein gene with familial Alzheimer's disease. Nature 1991;349:704-706.

3. Sherrington R, Froelich S, Sorbi S, et al. Alzheimer's disease associated with mutations in presenilin 2 is rare and variably penetrant. Hum Molec Genet 1996;5:985-988.

4. Levy-Lahad E, Wijsman EM, Memens E, et al. A familial Alzheimer's disease locus on chromosome 1. Science 1995;269:970-973.

5. Tanzi RE, Bertram L. New frontiers in Alzheimer's disease genitics. Neuron 2001;32:181-184.

6. Strittmatter W, Saunders AM, Schmechel D, et al. Apolipoprotein E: highavidity binding to $\beta$-amyloid and increased frequency of type 4 allele in late- onset familial Alzheimer disease. Proc Natl Acad Sci USA 1993; 90:1977-1981.

7. Mayeux R, Stern Y, Ottman R, et al. The apolipoprotein E4 allele in patients with Alzheimer's disease. Ann Neurol 1993;34:752-754.

8. Saunders AM, Strittmatter WJ, Schmechel D, et al. Association of apolipoprotein E allele E4 with late-onset familial and sporadic Alzheimer's disease. Neurology 1993;43:1467-1472.

9. Regland B, Blennow K,Germgard T, et al. The role of polymorphic genes apolipoprotein $\mathrm{E}$ and methylenotetrahidrofolate reductase in the development of dementia of Alzheimer type. Dement Geriatr Cogn Disord 1999;10:245-251

10. Farrer LA, Cupples LA, Haines JL, et al. Effects of age, sex, end ethnicity on the association between apolipoprotein E genotype and Alzheimer disease: a meta-analysis. JAMA 1997;278:1349-1356.

11. Blacker D, Haines JL, Rods L, et al. ApoE4 and age at onset of Alzheimer's disease: the NIMH.genetics iniciative. Neurology 1997;48:139-147.

12. Lendon CL, Ashall F, Goate AM. Exploring the etiology of Alzheimer disease using molecular genetics. JAMA 1997;277:825-831.

13. Tol J, Roks G, Slooter AJC, et al. Genetic and environmental factors in Alzheimer's disease. Rev Neurol (Paris) 1999;155:(Suppl 4):S10-S16.

14. Blacker D, Tanzi RE. The genetics of Alzheimer disease: current status and future prospects. Arch Neurol 1998;55:294-296.

15. Selhub J, Bagley LC, Miller J, et al. B vitamins, homocysteine, and neurocognitive function in the elderly. Am J Clin Nutr 2000;71(Suppl):S614-S620.

16. Snowdon DA, Tully CL, Smith CD, et al. Serum folate and the severity of atrophy of the neocortex in Alzheimer disease: findings from the Nun Study. Am J Clin Nutr 2000;71:993-998.

17. Miller JW. Homocystein, Alzheimer's disease, and cognitive function. Nutricion 2000;16:675-677. 
18. Nourhashémi F, Gillette-Guyonnet $S$, Andrieu S, et al. Alzheimer disease: protective factors. Am J Clin Nutr 2000;71(Suppl):S643-S649.

19. Clarke R, Smith AD, Jobst KA, et al. Folate, vitamin B12, and serum total homocysteine levels in confirmed Alzheimer disease. Arch Neurol 1998;55:1449-1455.

20. Nishiyama M, Kato $Y$, Hashimoto M, et al. Apolipoprotein E, methylenetetrahydrofolate reductase (MTHFR) mutation and the risk of senile dementia- an epidemiological study using the polymerase chain reaction (PCR) method. Epidemiology 2000;10:163-172.

21. Mc Khann G, Drachman D, Folstein M, et al. Clinical diagnosis of Alzheimer's disease: report of the NINCDS-ADRDA work group under the auspices of Department of Health and Human Service Task force on Alzheimer's Disease. Neurology 1984;34:939-944.

22. Cummings Jl, Benson DF.Dementia of the Alzheimer type: an inventory of diagnostic clinical features. JAGS 1986;34:12-19.

23. Wenham PR, Price WH, Blundell G. Apolipoprotein E genotyping by one-stage PCR. Lancet 1991;337:1158-1159.

24. Simopoulus AP. Genetic variations and nutrition. Nutrition Reviews 1999;57:S10-S19.

25. Andrade FM, Larrandaburu M, Callegari-Jacques SM, et al. Association of apolipoprotein E polymorphism with plasma lipids and Alzheimer's disease in a Southern Brazilian population. Braz J Med Biol Res. 2000;33:529-537.

26. Schwanke CHA, Cruz IBM, Leal NF, et al. Analysis of association between apolipoprotein E polymorphism and cardiovascular risk factors in na elderly population with longevity. Arq Bras Cardiol 2002;78:571-579.

27. Almeida OP, Shimokomaki CM. Apolipoprotein E4 and Alzheimer's disease in São Paulo-Brazil. Arq Neuropsiquiatr 1997;55:1-7.

28. Molero AE, Pino-Ramirez G, Maestre GE. Modulation by age and gen- der of risk for Alzheimer's disease and vascular dementia associated with the apolipoprotein E-E4 allele in Latin Americans: findings from Maracaibo Aging Study. Neurosci Letters2001;307:5-8.

29. Myers AM, Goate AM. The genetics of late-onset Alzheimer's disease. Curr Opin Neurol 2001;14:433-440.

30. Selkoe DJ. Alzheimer's disease: genes, proteins and therapy. Phisiol Rev 2001;81:741-766

31. Lippa CF, Smith TW, Saunders AM, et al. Apolipoprotein E epsilon 2 and Alzheimer's disease: genotype influences pathologic phenotype. Neurology 1997;48:515-519.

32. Bradford-Hill A. The environment and disease: association or Causation? J R Soc Med 1965;58:295-300.

33. Postiglione A, Milan G, Ruoceo A, et al. Plasma folate, vitamine B12, and total homocystein and homozygosity for the C677T mutation of the 5,10 methylene tetrahydrofolate reductase gene in patients with Alzheimer's dementia: a case-control study. Gerontology 2001;47:324-329.

34. Brunelli T, Bagnoli S, Giusti B, et al. The C677T methylenetetrahydrofolate reductase mutation is not associated with Alzheimer's disease. Neurosci Letters 2001;315:103-105.

35. Prince JA, Feuk L, Sawyer SL, et al. Lack of replication of association findings in complex disease: an analysis of 15 polymorphisms in prior candidate genes for sporadic Alzheimer's disease. Eur J Hum Genet 2001 Jun;9:437-444.

36. Seripa D, Forno GD, Matera MG et al. Methylenetetrahydrofolate reductase and angiotensin converting enzyme gene polymorphisms in two genetically and diagnostically distinct cohort of Alzheimer patients. Neurobiol Aging, 2003;24:933-939.

37. Religa D, Styczynska M, Peplonska, B et al. Homocysteine, apolipoproteine $E$ and methylenetetrahydrofolate reductase in Alzheimer1s disease and mild cognitive impairment. Dement Geriatr Cogn Disord, 2003:16:64-70. 